ISSN: $2617-6548$

\title{
The Future Biology Teachers Training for the Implementation of Sustainable Development Ideas in Ecological Education
}

D Halyna Biletska1, (D) Nataliia Mironova², (D) Olha Yefremova ${ }^{3}$, (D) Liubov Barna ${ }^{4}$, (D) Ihor Bloshchynskyi*

\author{
${ }^{1,2,3}$ Department of Ecology and Biology Education, Khmelnytskyi National University, Ukraine. \\ ${ }^{4}$ Department of General Biology and Methods of Teaching Natural Science, Ternopil Volodymyr Hnatiuk National Pedagogical \\ University, Ukraine. \\ ${ }^{5}$ Foreign Languages Department, Bohdan Khmelnytskyi National Academy of the State Border Guard Service of Ukraine, Ukraine.
}

*Corresponding author: Ihor Bloshchynskyi (i.bloshch@gmail.com)

\begin{abstract}
The article presents the results of the experimental study targeted at the scientific substantiation and experimental verification of the methodology of the future biology teachers' ecological competence development. It is grounded and proved that ecological education resulting in ecological competence is an integral part of education for sustainable development. In order to integrate sustainable development education into the future biology teachers' training, the methodology for the ecological competence development has been suggested. The methodology involves the environmentalization of the educational content and the use of a modular object-oriented dynamic learning environment. A pedagogical experiment was conducted in order to determine the effectiveness of the methodology of future biology teachers training for the implementation of sustainable development ideas in ecological education. Four hundred and twenty-seven students participated in the experimental study. Control and experimental groups of students were allocated for conducting the experiment. In experimental groups the author's methodology was implemented. The experimental data were processed using mathematical statistics. As a result of the generalization of the results of the study, it was found that in the experimental groups, the percentage of students with high and medium levels of ecological competence increased, and with low levels - decreased compared to the control groups. This testifies to the effectiveness of the future biology teachers' ecological competence development.
\end{abstract}

Keywords: Sustainable development, Ecological education, Ecological competence, Future biology teachers.

DOI: $10.53894 /$ ijirss.v4i4.200

Funding: This study received no specific financial support.

History: Received: 26 July 2021/Revised: 30 August 2020/Accepted: 4 October 2021/Published: 22 November 2021

Licensed: This work is licensed under a Creative Commons Attribution 4.0 License (co) EY

Acknowledgement: All authors contributed to the conception and design of the study.

Competing Interests: The authors declare that they have no conflict of interests.

Transparency: The authors confirm that the manuscript is an honest, accurate, and transparent account of the study was reported; that no vital features of the study have been omitted; and that any discrepancies from the study as planned have been explained.

Ethical: This study follows all ethical practices during writing.

\section{Introduction}

The transition of the world community and the individual states to the model of sustainable development substantially 
transforms all spheres of social life. However, since the main and obligatory condition for sustainable development is the mentality transformation, the changes concern the science and education, having a prominent role in shifting the mental attitudes of people. The ecological education acts as a catalyst in turning humanity from a consumer way of life to a more environmentally friendly one. The field of ecological education related to the teachers training for environmental education of schoolchildren is especially relevant. It is logical and doubtless as far as the teacher plays a key role in shaping the ecological outlook and culture of the individual.

Since its inception, ecology has evolved as a biological science, so biological knowledge has a great potential for shaping the ecological outlook, and the biology teacher is given a leading role in the ecological education of schoolchildren. Therefore, the future biology teachers training at higher education institutions should be aimed at the development of knowledge, values and qualities that determine the active position of the individual in environmental protection, ensure the ability to carry out ecological education and implement ideas of sustainable development. This necessitates the integration of the ecological component into the future biology teachers training.

\subsection{The Aim}

The aim of the study is to develop, scientifically substantiate and experimentally verify the methodology of the future biology teachers' ecological competence development. The aim is specified in the following targets: 1) to substantiate the role of the ecological education in the future biology teachers' training for the implementation of the education for sustainable development ideas; 2) to find out the essence of the ecological competence of the future biology teachers, to determine the criteria and indicators of its development; 3) to create and implement in the future biology teachers' training the methodology of the ecological competence development; 4) to determine the effectiveness of the methodology of the future biology teachers' ecological competence development.

\section{Materials and Methods}

\subsection{Literature Review}

\subsubsection{Prerequisites for the Development of the Education for Sustainable Development Concept}

Education is the main prerequisite and principal mean of achieving the sustainable development goals. This issue is widely discussed at international governmental and non-governmental conferences. In the official documents it is emphasized that education is one of the driving factors for sustainable development, and teachers have a leading role in implementation of the social changes necessary for sustainable development. In the 21st Century Agenda it is underlined that the key task of education is to formulate environmental and ethical norms, values and attitudes, professional skills and lifestyles necessary for sustainable development [1]. The need for international agreements and actions in the sphere of education was declared at the Johannesburg [2]. According to the Summit recommendation, the UN General Assembly adopted a resolution proclaiming the Decade of Education for Sustainable Development from 2005 to 2014 [3].

The response of the European Community to the Johannesburg Summit Declaration was the adoption by the Ministers of Ecology of the United Nations Economic Commission member states of a statement on education for sustainable development. It was recognized that education was one of the main instruments that provide environmental protection and sustainable development [4]. In March 2005, in Vilnius, the representatives of the ministries of ecology and education adopted the UNECE Strategy for Education for Sustainable Development. It states that education for sustainable development contributes to changing people's attitudes and outlooks, motivates and encourages them to make the world safer, thereby enhancing the quality of life [5]. Ukraine has become one of the 55 states that have signed the UNECE Strategy for Education for Sustainable Development.

UNESCO has developed a Global Action Program on Education for Sustainable Development after 2014 and a roadmap for its implementation to consolidate the results of the Decade of Education for Sustainable Development and to provide education with new dynamics $[6,7]$.

At the 2015 UN Summit, leaders from all countries expressed support for the transition to sustainability through the implementation of the 17 Sustainable Development Goals by 2030 (New York, 2015). It was emphasized that high-quality education is the catalyst and prerequisite for achieving all the sustainable development goals [8]. In 2017, UNESCO developed recommendations on harnessing the potential of education to achieve each of the Sustainable Development Goals [9].

\subsubsection{Ecological Education for Sustainable Development}

The issues of education for sustainable development have been in focus for more than a decade. Scientists stress that education in the process of transition to a model of sustainable development has acquired two new functions. The first function is referred to as a neohumanistic. It implies the orientation of the educational process towards the survival and progress of mankind. The second function of education is ecological. It is focused on the conservation of the biosphere and nature, the provision of favorable environmental conditions and ensuring ecological safety. This function involves creating technologies providing protection for the atmosphere, water and land, energy and resource conservation, waste reduction etc. In education, ecological function means the introduction of professional ecological education and the general environmentalization of education [10].

In the UNECE Strategy for Education for Sustainable Development it is stated that the ecological education is of vital importance in the long-term process of establishing an integrated education system for sustainable development. As a constituent part of an integrated education system for sustainable development, ecological education retains the foundations of basic ecological education and at the same time provides new opportunities for interdisciplinary ecological and social, 
ecological and economic study of interaction within the society - nature system targeted at its harmonization [5].

At the same time, there should be a clear distinction between the education for sustainable development and the ecological education. Firstly, the education for sustainable development and the ecological education are based on the completely different cultural paradigms. The purpose of the ecological education is the comprehensive study and consideration of the environmental problems along with the search for ways to resolve this undoubtedly extremely complicated but hardly unsolvable problems. The education for sustainable development is not aimed at correcting what has already been done by man, but rather at preventing environmental problems and disasters [11, 12]. The education for sustainable development content is based on new approaches to the use of natural resources and the restoring issues. Moreover, the negative environmental impact is seen not only as a result of the misallocation of natural resources, but as a mismatch between existing environmental and consumption stereotypes to meet the needs of the future [13]. Apparently, only a new model of the ecological education commonly referred to as a noospheric education can ensure sustainable development of society. The purpose of the noospheric education is to form a culture in which the world is holistic and human is not opposed to it Burovskyi [11].

Secondly, the education for sustainable development is broader in content than the ecological education. It integrates three components: environmental, social and economic [14, 15]. The environmental component involves the study of environmental factors of sustainable development, in particular, the principles and laws of the nature and society development, the causes and consequences of the global environmental problems emerging predetermined by the society and nature interaction. The social component of the education for sustainable development provides the study of social factors such as quality and safety of life, moral and ethical principles of society, etc. The economic component involves studying the factors of socio-economic development, taking into account environmental constraints [14]. The combination of these components determines the main difference between the education for sustainable development and the ecological education.

\subsubsection{The Ecological Education in Ukraine}

Ukraine has the rich history of the ecological education. In Article 7 of the Law of Ukraine "On Environmental Protection" it is stated that "the enhancement of the ecological culture of society and professional training of specialists are ensured by the general compulsory comprehensive education in the field of environmental protection ... Ecological knowledge is a mandatory qualification requirement for all officials whose activities are related to the use of natural resources and environmental impacts" [16]. In compliance with the Law, since 1996, the discipline "Fundamentals of Ecology" ("Ecology") was introduced into the standards of higher education of Ukraine and curricula of all the majors. The principal purpose of the discipline implementation was to form ecological thinking, culture, consciousness and ability to environmentalize the professional activity.

Taking into consideration the current world trends in the education development, the Concept of Ecological Education in Ukraine was developed in 2002. The Concept is targeted at the creation of an effective training system to solve environmental problems in the country [17].

The necessity of the education environmentalization is declared in the Law of Ukraine "On Basic Principles (Strategy) of the State Environmental Policy of Ukraine for the Period up to 2030". The Law emphasizes that the education for sustainable development will enable continuous ecological education, increase the level of the ecological education and environmental outlook of Ukrainian citizens. Therefore, the conditions for the introduction of sustainable consumption patterns into the everyday life will be created. The role of the ecological education in preventing pollution of the environment, sustainable use of natural resources and restoration of Ukraine's natural resource potential will be activated [18].

At present, a range of theoretical principles of the ecological education remain relevant as far as they have not been implemented in pedagogical practice yet. This problem is of particular relevance in the context of developing a new generation of higher education standards in Ukraine. Higher education standards developed in Ukraine since 2015 are based on a competent approach. The standards include general requirements for graduates of higher education institutions, which are presented as the lists of competencies and learning outcomes. The Board of the Ministry of Education and Science of Ukraine "On the environmentalization of the higher education of Ukraine with the aim of training specialists for sustainable development" recommended the introduction of the ecological competence in the standards of higher education [19].

\subsubsection{The Role of Biology Teachers in the Implementation of the Ecological Education for Sustainable Development}

Ukrainian educators traditionally correlate the concepts of sustainable development and ecological education with environmental sciences, each of which explains the nature of ecological phenomena, environmental laws and global environmental problems based on their subjective conception of nature.

Ecology is particularly close to biology since ecology has emerged as a biological science that studies the patterns of interaction of living organisms with the environment. Ecology is now far beyond the content field of biology. At the same time, there is still a stereotypical perception of ecology as a biological science, and the content of school ecological education is dominated by the biological component. It could be reasonably argued that the biological meaning of the following ecological concepts prevails: Vernadskyi Doctrine about the biosphere, biological cycle of substances, living matter, ecosystem, succession, adaptation of living organisms, biodiversity, biological self-purification of water reservoirs, etc. The study of biology encompasses the understanding of the ecological features of living organisms, ecological groups 
of plants and animals, the ecological role of living organism [20]. Similarly, as a result of studying biology, the abilities to analyze and evaluate the impact of environmental factors on living organisms, to monitor the state of living organisms at different levels of their organization, to analyze the causes and consequences of the decline in the number and species of biocenosis are formed.

The ability of a biology teacher to implement the ecological education for sustainable development requires thorough training. Requirements for the competence of teachers in education for sustainable development are formulated in the recommendations of the United Nations Educational, Scientific and Cultural Organization [21]. The requirements are also widely presented in numerous pedagogical studies. Scholars emphasize that the implementation of the ecological education for sustainable development entails the demonstration by teachers' knowledge of teaching theory, ability to organize training and manage the educational process, the ability to motivate students, to cultivate their self-confidence [22]. It is stated that teachers should be capable of learning throughout life, being a role model for their students, stimulating such personal qualities as motivation for professional activity, creativity, innovation, resilience to stress [23]. The implementation of the ecological education for sustainable development, in addition to the above qualities, requires the development of a value attitude to nature, environmental awareness and ecological thinking [24]. Therefore, ecological competence occupies an important place in the structure of teacher professional competence [25, 26]. Taking into account the above-mentioned requirements for teachers and the results of scientific researches on the essence of the ecological competence of teachers of biology and environmental sciences, the definition of the ecological competence has been suggested. The ecological competence of a biology teacher has been defined as a personality characteristic that reflects the considerable body of ecological knowledge, motives, values and personal qualities that determine an active position in the field of environmental protection and ensure the ability to provide ecological education. The ecological competence should be an integrated outcome of the future biology teachers' ecological education, ensuring their ability to implement sustainable development in teaching.

\subsection{Participants}

The study was conducted at higher education institutions of Ukraine that provide training for future biology teachers. 24 teachers and 427 students participated in the experimental study.

\subsection{Research Procedure and Methods of Experimental Study}

\subsubsection{The Experimental Study on the Future Biology Teachers' Ecological Competence Development Involved Four Stages}

The first stage comprised the examination of the current state of the future biology teachers' ecological education. The criteria, indicators and levels of students' ecological competence were substantiated. The following research methods were used: observation of the educational process; analysis of scientific literature, educational programs and curricula; student surveys and questionnaires.

The second stage included the creation of the methodology of the future biology teachers' ecological competence development. The methodology comprises: 1) environmentalization of the future biology teachers' training content through the introduction of ecological courses and supplementing them with environmentally oriented educational content; 2) the use of a modular object-oriented dynamic learning environment (Moodle), which extends students' access to educational courses, provides active learning, and enables individual educational path creation. The main method used at the second stage was the content design of the educational and methodological support for the future biology teachers' training.

The following ecologically oriented courses were included in the compulsory part of educational program and curriculum of the future biology teachers' training: "General Ecology", "Technoecology", "Protection of Landscape and Biological Diversity", "Teaching Methodology". The main purpose was to develop students' ecological outlook by means of educational content. The ecologically oriented courses deliver the ecological knowledge, motives, values and personal qualities that determine an active position in the field of environmental protection and the ability to provide ecological education at schools.

The content of the courses for the future biology teachers ("Botany", "Zoology", "Methods of Teaching Biology") was supplemented with environmentally oriented educational material. In particular, the content of the course "Botany" included topics "Ecological features of spore and seed plants", "Features of ecology of algae, fungi and lichens", "Adaptation of plants to environmental conditions", "Ecological and economic importance of plants", "Impact of economic activity on the vegetation", "Protection of rare and endangered plants". The content of the course "Zoology" was supplemented with the topics "Ecological features of invertebrates", "Ecological features of vertebrates", "Trophic groups of animals", "Adaptation of animals to environmental conditions", "Ecological and economic importance of animals", "Impact of economic activity on the fauna", "Protection of rare and endangered animals". The content of the course "Methods of Teaching Biology" was supplemented by the topics "Methodology of teaching the fundamentals of ecology" and "Methodology of ecological and naturalistic work at school".

The corresponding e-courses have been developed in Moodle. Each course contained informational educational and methodological materials, laboratory or practical assignments, tasks for individual work that ensured the future biology teachers' ecological competence development, as well as tests for different types of control.

At the third stage of the experimental study the pedagogical experiment was carried out. The experiment involved the implementation of the summative and formative stages. At the summative stage, control and experimental groups (CG and EG) of students were identified and the level of their ecological competence development was determined. At the formative stage, the methodology of the future biology teachers' ecological competence development was introduced in the 
experimental groups. In the control groups, the teaching remained traditional.

The fourth stage involved generalizing the results of the experimental study and drawing conclusions about the effectiveness of the methodology of the future biology teachers' ecological competence development. The following research methods were used: analysis, comparison, generalization; methods of mathematical statistics.

\subsubsection{Methods of Data Collection and Analysis}

The criteria, indicators and levels have been defined and methods have been selected to determine and assess the future biology teachers' ecological competence development Table 1.

The validity of the pedagogical experiment results was tested using Pearson's criterion $\chi^{2}$ [27].

Table-1.

Criteria, indicators, levels and assessment methods of the future biology teachers' ecological competence development

\begin{tabular}{l|l|l}
\hline Criterion & Indicator & Assessment Methods \\
\hline $\begin{array}{l}\text { Cognitive } \\
\text { and Acivity }\end{array}$ & $\begin{array}{l}\text { Body of ecological } \\
\text { knowledge }\end{array}$ & Testing students in Moodle \\
\cline { 2 - 3 } & $\begin{array}{l}\text { Ability to use ecological } \\
\text { knowledge to provide } \\
\text { ecological education }\end{array}$ & $\begin{array}{l}\text { Analysis of the results of practical assignments (courses "Teaching } \\
\text { Methods in Biology" and "Teaching Methods in Ecology" }\end{array}$ \\
\hline \multirow{2}{*}{$\begin{array}{l}\text { Motivational } \\
\text { Axiological }\end{array}$} & $\begin{array}{l}\text { Formation of motives for } \\
\text { ecological education }\end{array}$ & $\begin{array}{l}\text { Student survey using the Professional Motivation Questionnaire (by } \\
\text { K. Zamfir, A. Rean's modification) [28] }\end{array}$ \\
\cline { 2 - 3 } $\begin{array}{l}\text { Awareness of the nature } \\
\text { Palue }\end{array}$ & $\begin{array}{l}\text { Student survey using the Eco-Value Dispositions Test (EDT) (by } \\
\text { V. Skrebets) [29] }\end{array}$ \\
\hline Positional & $\begin{array}{l}\text { Formation of the } \\
\text { environmental outlook }\end{array}$ & $\begin{array}{l}\text { Questionnaire for determination of ecocentric and anthropocentric } \\
\text { systems of environmental values (by S. Thompson \& M. Barton, } \\
\text { Adapted by I. Kryazh) [29] }\end{array}$ \\
\cline { 2 - 3 } & $\begin{array}{l}\text { Formation of ecological } \\
\text { consciousness }\end{array}$ & $\begin{array}{l}\text { The method of determining the subjectivization of natural objects (by } \\
\text { S. Deryabo, V. Yasvin) [30] }\end{array}$ \\
\hline
\end{tabular}

\section{Results}

The results of the experimental verification of the methodology of the future biology teachers' ecological competence development are presented in Table 2 .

Generalized data on the future biology teachers' ecological competence development are summarized in Figure 1. A diagram of the dynamics of the future biology teachers' ecological competence development before and after the experiment is presented in Figure 2.

Table-2.

Results of the experimental verification of the methodology of the future biology teachers' ecological competence development

\begin{tabular}{|c|c|c|c|c|c|c|c|c|}
\hline \multirow{4}{*}{ Level } & \multicolumn{8}{|c|}{ Number of Students } \\
\hline & \multicolumn{4}{|c|}{ Summative Stage } & \multicolumn{4}{|c|}{ Formative Stage } \\
\hline & \multicolumn{2}{|c|}{ CG } & \multicolumn{2}{|c|}{ EG } & \multicolumn{2}{|c|}{ CG } & \multicolumn{2}{|c|}{ EG } \\
\hline & persons & $\%$ & persons & $\%$ & persons & $\%$ & persons & $\%$ \\
\hline \multicolumn{9}{|c|}{ Cognitive and Activity Criterion } \\
\hline Low & 114 & 54.03 & 114 & 52.78 & 81 & 38.39 & 58 & 26.85 \\
\hline Medium & 78 & 36.97 & 80 & 37.04 & 93 & 44.08 & 110 & 50.93 \\
\hline High & 19 & 9.00 & 22 & 10.18 & 37 & 17.53 & 48 & 22.22 \\
\hline \multicolumn{9}{|c|}{ Motivational and Axiological Criterion } \\
\hline Low & 79 & 37.44 & 82 & 37.96 & 62 & 29.38 & 42 & 19.44 \\
\hline Medium & 98 & 46.45 & 103 & 47.69 & 108 & 51.19 & 119 & 55.09 \\
\hline High & 34 & 16.11 & 31 & 14.35 & 41 & 19.43 & 55 & 25.47 \\
\hline \multicolumn{9}{|c|}{ Outlook and Positional Criterion } \\
\hline Low & 107 & 50.71 & 113 & 52.31 & 76 & 36.02 & 49 & 22.68 \\
\hline Medium & 81 & 38.39 & 79 & 36.58 & 97 & 45.97 & 114 & 52.78 \\
\hline High & 23 & 10.90 & 24 & 11.11 & 38 & 18.01 & 49 & 24.54 \\
\hline
\end{tabular}




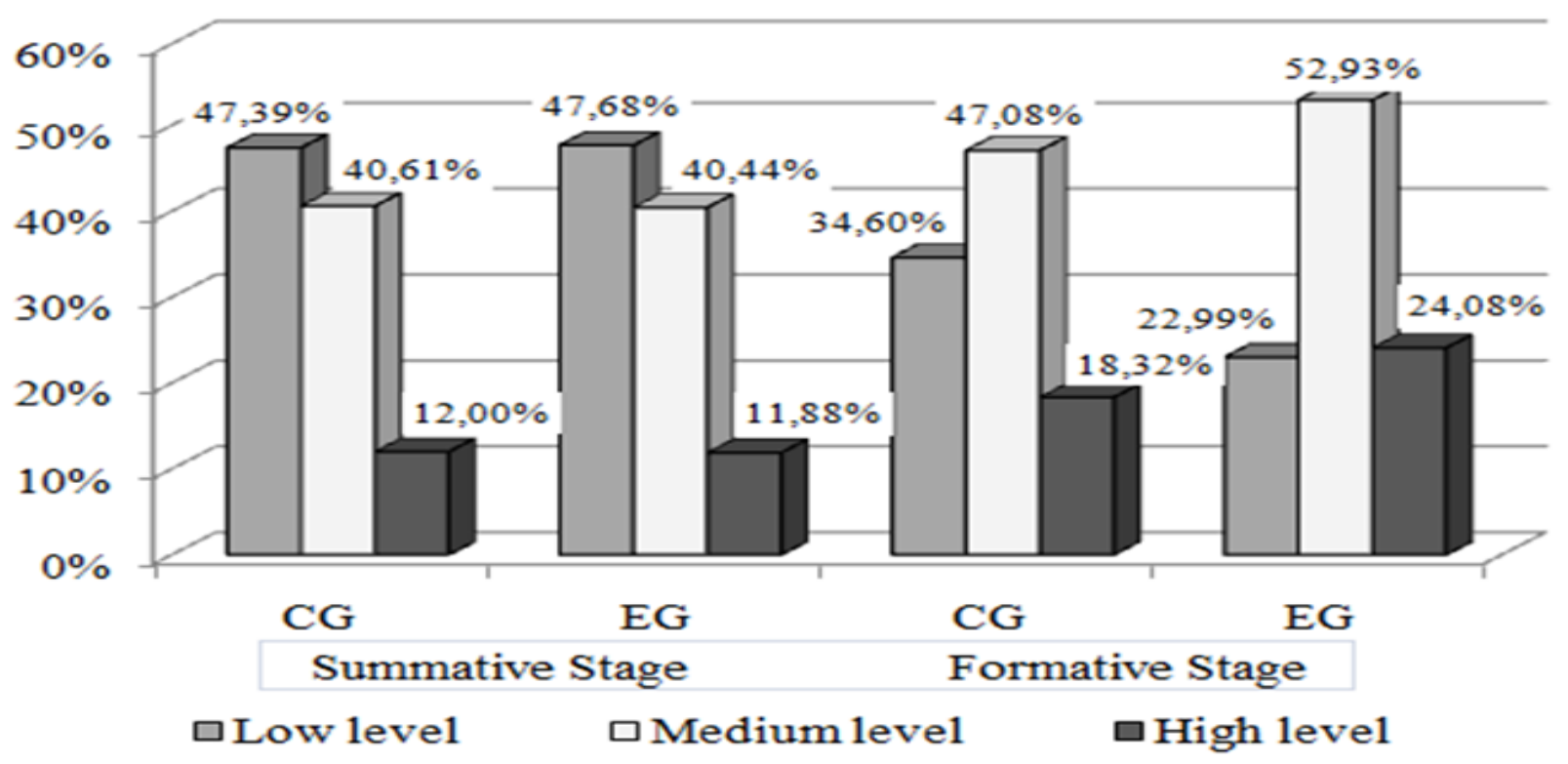

Figure-1.

Diagram of the distribution of students in control and experimental groups by levels of environmental competence development.

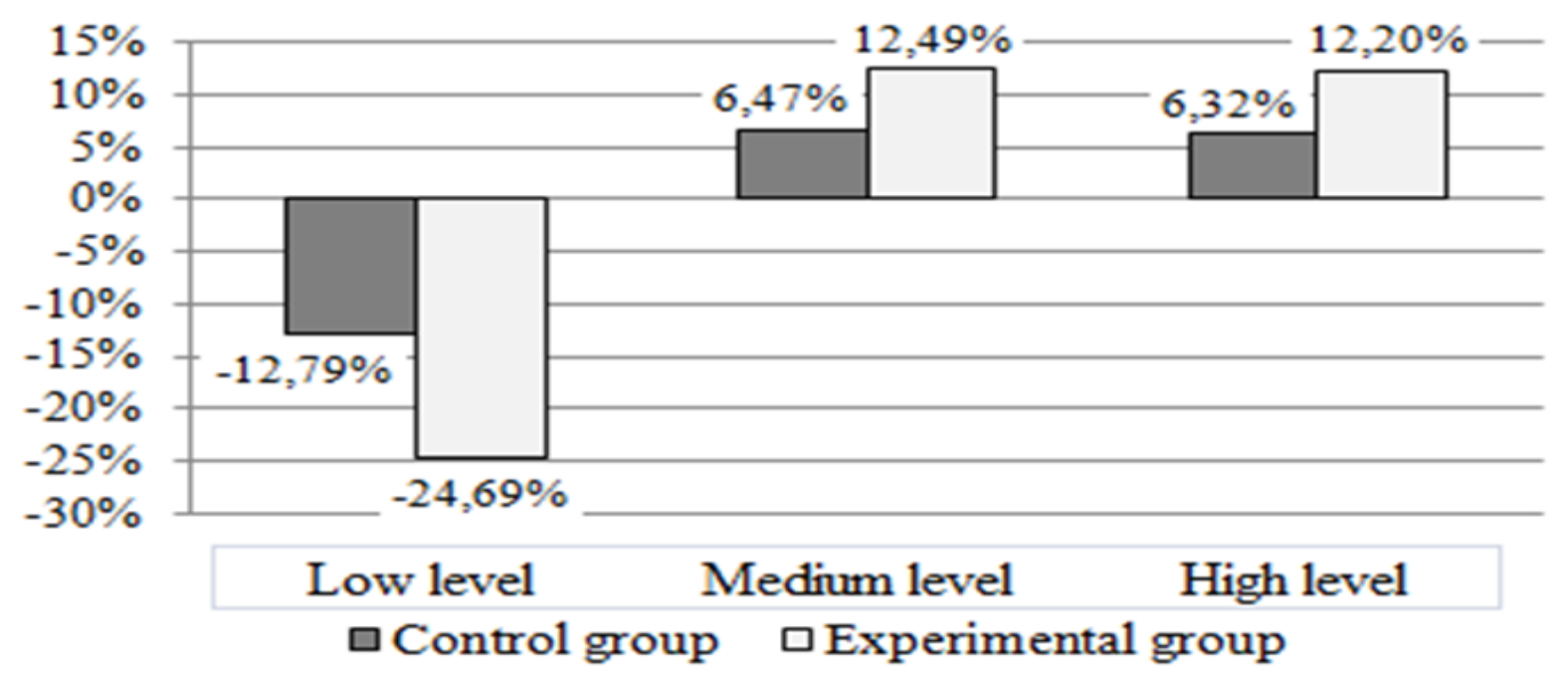

Figure-2.

Diagram of the dynamics of the future biology teachers' ecological competence development level change before and after the experiment.

Let us analyze the results of experimental study of the future biology teachers' ecological competence development.

During the summative stage of the pedagogical experiment, it was found that the majority of students of control and experimental groups (Figure 1) have a low level of environmental competence (CG 47.39\%, EG 47.68\%). The medium level is typical for $40.61 \%$ of CG students and $40.44 \%$ of EG students. Only $12 \%$ of CG students and $11.88 \%$ of EG students have a high level of environmental competence. The low level of environmental competence development among future biology teachers is an obstacle to the qualitative ecological education of students and the implementation of sustainable development ideas in their professional activities.

After the formative stage of the pedagogical experiment (Figure 2), the number of students with high level of ecological competence increased by $12.02 \%$, and among the students with medium level by $12.49 \%$ (in CG, $6.32 \%$ and $6.47 \%$, respectively). In addition, compared to $\mathrm{CG}$, the percentage of students with low levels of environmental competence has significantly reduced. In particular, the number of students with low levels of environmental competence decreased by $24.69 \%$ in the EG, and only by $12.79 \%$ in the CG.

The value of the Pearson criterion $\chi^{2}$ in the control and experimental groups before and after the introduction of the methodology of the future biology teachers' ecological competence development is presented in Table 3.

The results of the pedagogical experiment and their statistical verification according to the Pearson criterion $\chi^{2}$ made it possible to conclude on the effectiveness of methodology of the future biology teachers' ecological competence development. 
Table-3.

The value of the Pearson criterion $\chi^{2}$ in the control and experimental groups before and after the formative stage of the pedagogical experiment.

\begin{tabular}{c|cc}
\hline Summative Stage & Formative Stage \\
\hline$\chi_{\text {emp. }}^{2}<\chi_{\text {cr. }}^{2}$ & Cognitive and Activity Criterion \\
\hline $0.19<5.99$ & $\chi_{\text {emp. }}^{2} \chi_{\text {cr. }}^{2}$ \\
\hline \multicolumn{3}{|c}{ Motivational and Axiological Criterion } \\
\hline $0.26<5.99$ & $6.60>5.99$ \\
\hline & Outlook and Positional Criterion \\
\hline & & $6.36>5.99$ \\
\hline
\end{tabular}

\section{Discussion \& Conclusions}

The concept of education for sustainable development has significantly influenced the priorities of professional training of specialists in various fields. However, the ideas of education for sustainable development have not been properly implemented in the future biology teachers' training. For the implementation of education for sustainable development, scientists propose to introduce in the specialists training a special course "Sustainable Development Strategy"; to develop methodological literature and guides for educators on teaching sustainable development issues [3133]. A considerable range of studies is devoted to the tools, methods and technologies for delivering education for sustainable development. Educators are unanimous in their view that education for sustainable development requires the use of methods and cognitive resources that contribute to the involvement of each individual in dialogue and cooperation with regard to its individual characteristics, the formation of student behavior models considering sustainable development ideas (interactive methods, project technologies, information and communication technologies, participating in ecological research expeditions, environmental excursions and hikes, etc.) [34,35]. One of the ways of implementing education for sustainable development is the environmentalization of the education content $[13,36]$.

In the context of our study, the research papers devoted to the implementation of the ecological education for sustainable development ideas in the future biology teachers' training are of the greatest interest [35, 37]. We have also worked with the studies concerned with the problems of the biology teachers' ecological competence development; the training of the biology teachers for the environmental education of schoolchildren [38-40]. Scientists state that the future biology teachers training should be focused on ecological education. Therefore, it is necessary to introduce in the future biology teachers training educational courses that provide the ecological outlook and ecological culture development. The disciplines should be targeted at the formation of the ability to provide ecological education of schoolchildren, environmentalization of the disciplines content, use of methods and technologies that contribute to the formation of an active individual environmental position [26, 35, 41].

The comprehensive study of the issues of the introduction of education for sustainable development ideas in the future biology teachers' training was conducted by N. Levchuk and A. Stepaniuk. In their opinion, there are two ways of integrating education for sustainable development into the professional training of biology teachers: 1) through the formation of ecological outlook by means of content of educational material; 2) as a result of the introduction of innovative teaching technologies. The technologies involve active perception of the educational material, formation of the ability to express and defend their own point of view, to think critically, to work in a team, to respect democratic decisions [37]. We have taken into account the above-mentioned positions in the process of creating a methodology for environmental competence development.

The effectiveness of the methodology of the future biology teachers' ecological competence development, in our opinion, is proved by the fact that ecological educational courses and ecological component of the professional disciplines content provide formation of ecological knowledge and ability to use it for ecological education of schoolchildren and professional expediency (cognitive and activity criterion). The ecological component increases the motivation for realization of ecological education and realization of sustainable development ideas in pedagogical activity (motivational and axiological criterion). It also contributes to students' awareness of modern environmental problems and the need not only to solve them, but also to prevent in the future, which ensures the sustainable development of society (outlook and positional criterion).

Formation of the future biology teachers' ecological knowledge was observed during the study of the following courses "General Ecology", "Technoecology", "Protection of Landscape and Biological Diversity", "Methodology of Teaching Ecology" and ecological topics of the courses "Botany", "Zoology", "Methodology of Teaching Biology". We believe that the use of Moodle influenced the ecological competence development in a positive way. Informative educational and methodical materials of electronic courses provided formation of ecological knowledge. The content and structure of electronic courses fully corresponded to the lectures of the disciplines. Using informative educational and methodical materials, students had the opportunity to prepare for the lecture in advance and to perceive theoretical material more efficiently in the class, to ask questions to the teacher, to clarify ambiguous issues and so on. To enhance students' work, teachers have pre-posted lectures or links to materials in Moodle. That revealed the value of a topic for a biology teacher's professional work.

Formation of the ability to use ecological knowledge in professional pedagogical activity was provided during practical sessions of the following courses "Methods of Teaching Ecology" and "Methods of Teaching Biology". As a part of practical assignments, students developed summaries of ecology and biology lessons, summaries of extracurricular ecological activities and, thus, acquired the ability to provide ecological education for schoolchildren. Practical assignments 
were designed for the students to be able to do the tasks independently, and the role of the teacher was limited to counseling. This contributed to the formation of conscious ecological knowledge, initiative and creativity of the future biology teachers.

Awareness of the value of nature and increasing the motivation for ecological education of schoolchildren promoted realizing and understanding of modern ecological problems and their consequences, perception of the necessity of their solution and prevention in the future while studying a range of courses, namely "General Ecology", "Technoecology", "Protection of Landscape and Biological Diversity". Environmentalization of the content of the courses "Botany", "Zoology" and "Methods of Teaching Biology" contributed to the understanding of the importance of ecological knowledge for biology teachers. Student learning became more motivated. The development of students' stable motives to study ecological courses was facilitated by Moodle. The learning environment provided free and widespread access to educational resources, students were able to choose a convenient time to work independently, to follow the electronic journal of their assessments, which, alongside with the use of computer-based testing, provided transparency and objectivity in evaluating learning outcomes.

Formation of ecological knowledge, awareness of the value of nature, understanding of the ecological education importance for the sustainable development of society contributed to the formation of the future biology teachers' ecological outlook awareness.

It is grounded and proved that ecological education resulting in ecological competence is an integral part of education for sustainable development. In order to integrate sustainable development education into the future biology teachers' training, the methodology for the ecological competence development has been suggested. The methodology involves the environmentalization of the educational content and the use of Moodle, which provides active learning and enhances student access to courses. The effectiveness of the methodology of the ecological competence development is confirmed experimentally and testifies to its expedient introduction into the future biology teachers' training.

\section{References}

[1] Agenda, "Agenda 21 United Nations Conference on Environment and Development, Rio De Janerio, Brazil, 3-14 June. Retrieved from https://sustainabledevelopment.un.org/content/documents/Agenda21.pdf," 1992.

[2] Johannesburg, "Johannesburg declaration on sustainable development and plan of implementation of the World Summit on Sustainable Development. Retrieved from https://unesdoc.unesco.org/ark:/48223/pf0000200168. [Accessed 24.03.2020]," 2003.

[3] UNESCO UN Decade of ESD, "Retrieved from https://en.unesco.org/themes/education-sustainable-development/what-isesd/un-decade-of-esd," 2002.

[4] Statement on Education for Sustainable Development by the UNECE Ministers of the Environment, "Retrieved from: https://unece.org/fileadmin/DAM/env/efe/Kiev/proceedings/files.pdf/Item\%2011/11Documents/ece.cep.102.rev.1.e.pdf," 2003.

[5] UNECE Sustainable Development Strategy, "Retrieved from: https://digitallibrary.un.org/record/545239," 2005.

[6] UNESCO, "UNESCO proposal for a global action programme on education for sustainable development as follow-up to the United Nations Decade of Education for Sustainable Development (DESD) after 2014, 2013. Retrieved from https://unesdoc.unesco.org/ark:/48223/pf0000224368," 2013.

[7] UNESCO, "UNESCO roadmap for implementing the global action program on education for sustainable Development, 2014. Retrieved from https://unesdoc.unesco.org/ark:/48223/pf0000230514," 2014.

[8] United Nations, "17 goals to transform our world. Retrieved from: https://www.un.org/sustainabledevelopment/," 2017.

[9] UNESCO, "UNESCO education for sustainable development goals: Learning objectives, 2017. Retrieved from https://unesdoc.unesco.org/ark:/48223/pf0000247444," 2017.

[10] A. Ursul, "The model of advanced education: noospheric-ecological aspect. Philosophy of Ecological Education. Moscow, Progress-Tradition, Monograph, 49-71. Russia," 2001.

[11] A. M. Burovskyi, "The philosophical foundations of environmental education. Philosophy of Ecological Education. Moscow, Progress-Tradition, Monograph, 255-286. Russia," 2001.

[12] A. I. Santos and S. Serpa, "Flipped classroom for an active learning," Journal of Education and E-Learning Research, vol. 7, pp. 167-173, 2020.Available at: https://doi.org/10.20448/journal.509.2020.72.167.173.

[13] O. E. Vysotska, "Education for sustainable development," ed Ukraine: Dnipropetrovsk, Royal Print, 2011, p. 200.

[14] V. M. Boholiubov, "Conceptual approaches to shaping education for sustainable development, collection of scientific articles of the " presented at the Third All-Ukrainian Congress of Ecologists with International Participation, 2011.

[15] I. Koreneva, "The phenomenon of" education for sustainable development": The essence and modern features of the concept," Ukrainian Pedantic Magazine, vol. 2, pp. 113-123, 2018.

[16] Law of Ukraine, "On environmental protection", 1991, 2019. Retrieved from https://zakon.rada.gov.ua/laws/show/1264-12. [Accessed 28.05.2020]," 2019.

[17] Concept of Ecological Education in Ukraine, "Retrieved from: http://www.uazakon.com/document/spart20/inx20787.htm," 2002 .

[18] Law of Ukraine, "On the fundamental principles (Strategy) of the state environmental policy of Ukraine for the period up to 2030. Retrieved from https://zakon.rada.gov.ua/laws/show/2697-19\#n8. [Accessed 28.05.2020]," 2019.

[19] Decision of the Collegium of the Ministry of Education and Science of Ukraine, "On environmentalization of higher education of Ukraine with the purpose of training specialists for sustainable development. Retrieved from http://mon.gov.ua/about/kolegiya-ministerstva/rishennya-kolegiyi-ministerstva.html. [Accessed 28.05.2020]," 2015.

[20] M. S. Bahov, "Natural science foundations and national-regional aspects of environmental education and upbringing of secondary vocational school students," The Dissertation for the PhD in Pedagogical Sciences, Maykop, Russia, 2000.

[21] UNESCO, "UNESCO learning for the future: Competences in education for sustainable developmen. Retrieved from https://www.unece.org/fileadmin/DAM/env/esd/6thMeetSC/Learning\%20for\%20the\%20Future \%20Competences $\% 20$ for $\% 20$ Educators\%20in\%20ESD/ECE CEP AC13 2011 6\%20COMPETENCES\%20EN.pdf. [Accessed 24.03.2020]," 2011. 
[22] O. I. Pometun, "Pedagogical principles of education for sustainable development in the Ukrainian School," Ukrainian Pedagogical Journal, vol. 1, pp. 171-82, 2015.

[23] S. Ghorbani, S. E. M. Jafari, and F. Sharifian, "Learning to be: Teachers' cmpetences and practical solutions: A step towards sustainable development," Journal of Teacher Education for Sustainability, vol. 20, pp. 20-45, 2018.Available at: https://doi.org/10.2478/jtes-2018-0002.

[24] S. Bachri, A. Baidowi, and M. Aliman, "Problem-based service learning's effect on environmental concern and ability to write scientific papers," International Journal of Instruction, vol. 13, pp. 161-176, 2020.Available at: https://doi.org/10.29333/iji.2020.13411a.

[25] S. Rudyshyn and I. Koreneva, "Samilyk VI ecological competence as a general competence of the teacher of natural disciplines," Ukrainian Pedantic Magazine, vol. 3, pp. 74-83, 2016.

[26] M. M. Bilianska, "Theoretical and methodological bases of preparation of future biology teachers for ecological-pedagogical activity," The Dissertation for the PhD in Pedagogical Sciences, Kyiv, Ukraine, 2018.

[27] V. E. Bereka and M. P. Volovyk, "Theory of mathematics and statistics in pedagogy," ed Ukraine: Khmelnytskyi, KHPA, 2010, p. 250.

[28] D. Raihorodskyi, "Practical psychodiagnostics. Methods and Tests. Samara, Bakhrakh-M," p. 672, 2002.

[29] V. O. Skrebets and I. I. Shlimakova, "Environmental psychology," ed Ukraine: Kyiv, Slovo, 2014, p. 456.

[30] S. D. Deriabo and V. A. Yasvyn, "Environmental pedagogy and psychology," ed Russia: Rostov-na-donu, Feniks, 1996, p. 480.

[31] V. M. Boholiubov, "Theoretical and methodological principles of formation of professional competence of future ecologists in conditions of transition to sustainable development of society," Abstract of the Dissertation for the PhD in Pedagogical Sciences, Kyiv, Ukraine, 2014.

[32] M. Klymenko, A. Pryshchepa, L. Klymenko, and O. Brezhytska, "Educational and methodological support of education for sustainable development," New Pedagogical Thought, vol. 1, pp. 151-153, 2012.

[33] N. Havrysh and O. Pometun, "Education for sustainable development," ed Ukraine: Kyiv, Polyprint, 2019 , p. 96.

[34] O. I. Pometun., "Preparing teachers for teaching sustainable development," ed Ukraine: Kyiv, Pedagogical Thought, 2015, p. 120.

[35] N. A. Pustovit, "Education for sustainable development is an important direction for enhancing the environmental competence of teachers," Bulletin of Zhytomyr Ivan Franko State University, vol. 28, pp. 19-22, 2006.

[36] O. I. Bondar, V. I. Baranovska, and O. V. Yeresko, "Environmental education for sustainable development in questions and answers," ed Ukraine: Kherson, Hrin D. S., 2015, p. 228.

[37] N. V. Levchuk and A. V. Stepaniuk, "Training a future science teacher for environmental education activities based on sustainable development," in Scientific Proceedings: Peddagogics, 2010, pp. 20-24.

[38] Y. O. Lohvinova, "Ecological competence development of the future biology teacher in the process of studying natural sciences," Abstract of the Dissertation for the PhD in Pedagogical Sciences, Kirovohrad, Ukraine, 2014.

[39] L. M. Tytarenko, "Ecological competence development of students of biological majors at the university," Abstract of the Dissertation for the PhD in Pedagogical Sciences, Kyiv, Ukraine, 2007.

[40] V. V. Tanska, "Preparation of future biology teacher for environmental education of high school students," Dissertation for the PhD in Pedagogical Sciences, Zhytomyr, Ukraine, 2006.

[41] A. V. Stepaniuk and O. S. Trotska, "Environmentalizaion of the biological education content in terms of profile training," in Proceedings of the All-Ukrainian Scientific-Practical Conference "Organization \& Implementation of Profile Education in the Classes of Science and Mathematics”, Ukraine, 22-25 February, 2010. 